\title{
IAMJ
}

INTERNATIONAL

AYURVEDIC

MEDICAL JOURNAL

\section{COMPARATIVE ANALYSIS AND SEASONAL USES OF DIFFERENT ANIMAL SOURCES OF MILK GIVEN IN VARIOUS AYURVEDA TEXTS}

\author{
Rana Shivani $^{1}$, Pathania Deepak ${ }^{2}$, Jagota Ankush ${ }^{3}$ \\ ${ }^{1}$ MD Scholar Dept. of Swasthavritta, \\ ${ }^{2} \mathrm{MD}$ Scholar Dept. of Kaumarbhritya, \\ ${ }^{3}$ Lecturer Dept. of Swasthavritta, \\ R.G.G.P.G. Ay. College \& Hospital Paprola, District Kangra, Himachal Pradesh, India
}

Corresponding Author: shivanimona94@gmail.com

https://doi.org/10.46607/iamj3008102020

(Published online: October 2020)

Open Access

(C) International Ayurvedic Medical Journal, India 2020

Article Received: 02/09/2020 - Peer Reviewed: 26/09/2020 - Accepted for Publication: 27/09/2020

Check for updates

\section{ABSTRACT}

Ayurveda is one of the most ancient medical sciences of the world. It is more life \& health oriented. It emphasizes much more on diet \& regimen along with medicine. Milk is one of the animal origins Dravya which is important for people of all age groups as a dietary supplement $\&$ can be taken every day. Milk is beneficial for healthy individuals. The one who consumes milk doesn't get the disease. Hence there is no better Vrishya Dravya (Aphrodisiac) and no better Jeevaniya Dravya (life prolonger) than milk. Milk is considered as Rasayana (Rejuvenative). Seasonal regimen has been described in our texts. The prime principle of Ayurvedic system of medicine is preventive aspect, can be achieved by change in diet \& practices in response to change in climatic condition. In Ayurve$d a$ texts, milk of eight different animals i.e. milk of cow, buffalo, goat, camel, human, sheep, elephant $\&$ single hoofed animals like horse, donkey etc. has been described with a set of different properties. Milk of cow, buffalo, goat $\&$ sheep is easily available in our area. The objective of this is to establish the use of different milk in different seasons based on the properties described in our Ayurveda texts. An attempt has been made for use of cow milk, buffalo milk, goat milk \& sheep milk according to season through this paper. 
Keywords: Milk, Season, Rasayana.

\section{INTRODUCTION}

Ayurveda being the science of life, propagates the gift of nature in maintaining healthy \&happy living. It emphasizes much more on diet $\&$ regimen along with medicine. Trigunatmic diet has been described in our classics i.e. Satvika, Rajashik \& Tamashik. Among these Satvika diet is conducive to higher thought \& deep understanding, as well as to a body free from disease. Milk \& Milk products belong to Satvika foods that are pure, essential, nourishing, appealing \& succulent. Milk enhances the strength of body immediately, strengthens the senses, and provides intelligence, longevity, health /soundness\& happiness and it is considered as main Rasayana. ${ }^{[1]}$ In Ayurveda texts it is described that milk should be taken every day. ${ }^{[2]}$ Milk is beneficial for both physical as well as mental health. It also acts as memory booster. Milk increases the Oja in our body. According to Ayurveda, Oja is regarded to be the purest part of the seven Dhatus and is referred to as Bala by Acharya Sushruta, the body's natural immunity. Our physical, mental \& spiritual strength is totally dependent on Oja. In Ayurveda it is known as Vyadhikshamata i.e. immunity. There is no better Vrishya Dravya (Aphrodisiac) and no better Jeevaniya Dravya (life prolonger) than milk. ${ }^{[3]}$ In Ayurvedic texts, milk of eight different animals i.e. milk of cow, buffalo, goat, sheep, camel, human, elephant \& single hoofed animals like horse, donkey etc. has been described with a set of different properties. In general all types of milk is Madhura (Sweet in taste), Snigdha (Demulcent), Vata - Pittahara ( Subsides Vata and Pitta Doshas), Sara (Laxative), Sadya Sukrakara (Increases semen), Sheeta (Cold in potency), Satmya (Suitable to all), Jeevana (life promoting), Brimhana (Weight promoting), Balya (Strengthener), Medhya (Brain tonic), Vajikara (Aphrodisiac), Vyasthapana (Anti-aging), Ayushya (longevity), Sandhanakara (Heals the fractures), Rasayana (Tissue vitalizer) ${ }^{[4]}$. In our area cow, goat, buffalo and sheep milk is easily available. Acharaya Sushruta has been mentioned that raw milk is usually Abhishyandi and heavy to digest but after boiling is becomes light to digest and non Abhishyandi. So, all the milk should be used after boiling, except human milk. ${ }^{[5]}$ Milk is described as the nearly perfect food of the nature for all age groups. It is also called best \& complete food. Milk is a very wholesome food, because it contains almost all nutrients, except Iron $\&$ Vitamin C. It is a richest source of Calcium. It is easily digestible \& very essential for the young for their growth \& development ${ }^{[6]}$. The prime principle of Ayurvedic system of medicine is preventive aspect, can be achieved by change in diet \& practices in response to change in climatic condition. The concept of "Yat Pinde Tat Brahmande" (whatever there is in the environment is also there is in the human body) was applied, which led to appreciating changes in the human body according to seasons and regimens were made accordingly. Different seasons have been described in our texts. Each has their own characteristics. For prevention of disease \& promotion of health, diet should be according to the season.

\section{Aim and Objectives}

1. To study the description of cow, buffalo, goat and sheep milk in Ayurvedic classics elaborately.

2. To study the nutritional value of cow, buffalo, goat and sheep milk.

3. To establish the use of different milk in different seasons.

Material \& Methods: The different properties of Cow, Buffalo, Goat and Sheep milk are mentioned in our texts. According to Acharya Sushruta, milk of Go, Mahishi \& Aavi are Madhura(sweet) in taste, Guru (heavy in digestion), Snigdha (demulcent) \& these are Sheeta (cold in potency) except Aavi which is Ushna (Hot). Among these Mahishi dugdha is Ati Guru, Ati Snigdha. Whereas Aja Dugdha is Madhura(sweet) and Laghu (light). ${ }^{[7]}$

According to Acharya Charaka, Godugdha is Madhura (Sweet) in taste, Sheeta Virya (Hot) in potency, Mrudu (Softening the tissues), Snigdha (Demulcent), Bahala (Thick), Shlakshna (Smooth), Picchila (Sticky), Guru (Heavy), Manda (Dull), Prasan- 
$n a$ (Causes enthusiasm).Acts as Rasayana (Vitalizer) \& Oja Vruddhikar (Increases essence of all the seven Dhatus; Rasa-Rakta-Mansa-Meda-Asthi-MajjaShukra). The Aja Dugdha is Kashaya (Astringent), Madhura (Sweet) in taste, Sheeta (Cold) in potency \& Laghu (Light), Aavik Dugdha is Ushna (Hot) in potency \& the Mahishi Dugdha is more Guru (Heavy) \& Sheeta (Cold) in potency than Godugdha. ${ }^{[8]}$

Godugdha is Madhura (Sweet in taste), Madhura Vipaka (Sweet - post digestive effect), It is Guru (Heavy), Sheetala (Cooling), Stanyakrit (Promotes breast milk), Snigdha (Demulcent), subsides VataPitta and Rakta. The Avika Dugdha is Lavana (Salty), Swadu (Palatable), Snigdha (Demulcent), Ushna (Hot in potency), increase Kapha, Pitta \& Guru (Heavy). The Mahishi Dugdha is Maha-Abhishyandi (Causes blockage of the channels), Madhura (Sweet) in taste, Sheetala (Cooling), Snigdha (Demulcent) \& Guru (Heavy). The Aja dugdha is Madhura (Sweet), Kashaya (Astringent) in taste, Laghu (Light), Sheeta Virya (Cold in potency) \& Sarvaroganashaka cure all the diseases. ${ }^{[9]}$

Table 1: Showing properties of different milk as per Ayurvedic texts

\begin{tabular}{|l|l|l|l|l|}
\hline & Go Dugdha & Mahishi Dugdha & Aja Dugdha & Aavi Dugdha \\
\hline Rasa & Madhura & Madhura & Kashaya, Madhura & Madhura ${ }^{*}$ \\
\hline Guna & Guru, Snigdha & Ati Guru, Ati Snigdha & Laghu & Guru, Snigdha \\
\hline Virya & Sheeta & Ati Sheeta & Sheeta & Ushna \\
\hline Prabhava & $\begin{array}{l}\text { Vata- } \text { Pitta Shamaka, } \\
\text { Kapha vardhaka }\end{array}$ & $\begin{array}{l}\text { Vata- } \text { Pitta Shamaka, } \\
\text { Kapha vardhaka }\end{array}$ & $\begin{array}{l}\text { Vata vardhaka, } \\
\text { Pitta- Kapha Shamaka** }\end{array}$ & $\begin{array}{l}\text { Pitta } \\
\text { Kaphavardhaka }\end{array}$ \\
\hline
\end{tabular}

*Also Lavana by Acharya Bhav Prakash ** Sarvaroganashaka by Acharya Bhav Prakash

In Harita Samhita, different properties of Aavi Dugdha has been described. According to Acharya Harita, Aavi Dugdha is Madhura, Guru, Ruksha, Vata Kapha Shamaka and Pitta vardhaka. ${ }^{[10]}$ Nutritional Value (per 100 gram)

Milk has been described as the 'nearly perfect food' of the nature. It is easily digestible. The principal milk protein is casein. Other proteins are lactalbumin and lactoglobulin. Milk proteins contain all essential amino acids. Milk fat is a good source of carotene. The carbohydrate in the milk is lactose. Milk is the only natural source of lactose. ${ }^{[1]}$

Table 2: Showing nutritional value of different milk as per modern science.

\begin{tabular}{|l|l|l|l|l|}
\hline Component & Cow milk & Buffalo milk & Goat milk & Sheep milk \\
\hline Protein & 3.2 & 4.3 & 3.3 & 06 \\
\hline Fat & 4.1 & 6.5 & 4.5 & 07 \\
\hline Water & 88 & 83 & 87 & 80 \\
\hline Sodium & $40 \mathrm{mg}$ & $52 \mathrm{mg}$ & $50 \mathrm{mg}$ & $44 \mathrm{mg}$ \\
\hline Energy & $67 \mathrm{kcal}$ & $117 \mathrm{kcal}$ & $72 \mathrm{kcal}$ & $108 \mathrm{kcal}$ \\
\hline
\end{tabular}

Season and Milk: The season classified by different features express different effects on the body as well as the on environment. Ayurveda has depicted various rules and regimens (Charya), regarding diet and behavior to adjust seasonal enforcement easily without altering body homeostasis. The prime principle of Ayurvedic system of medicine is preventive aspect, can be achieved by change in diet \& practices in response to change in climatic condition.

Milk in different Seasons: Buffalo milk should be used in summer season i.e. in Greesham Ritu. The milk of Sheep is useful in Hemanta (beginning of winter). Cow's milk is like ambrosia for human beings during the rainy season i.e. in Varsha Ritu. ${ }^{[12]}$ 
According to Seasons Sanchaya (Accumulation), Prakopa (Aggravation) \& Prashamana (Pacification)

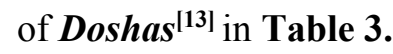

Table 3: Showing Sanchaya (Accumulation), Prakopa (Aggravation) \& Prashamana (Pacification) of Doshas in different seasons

\begin{tabular}{|c|c|c|c|}
\hline \multicolumn{1}{|l|}{ Dosa } & Sanchaya & Prakopa & Prashamana \\
\hline Vata & Greeshama & Varsha & Sharda \\
\hline Pitta & Varsha & Sharda & Hemanta \\
\hline Kapha & Shishira & Vasanta & Greeshama \\
\hline
\end{tabular}

Summer Season: Buffalo milk should be used in summer season i.e. in Greesham Ritu. In Greesham Ritu, accumulation (Sanchaya) of Vata dosha and pacification (Prashamana) of Kapha dosha occurs. Food which is light in process like those having Snigdha (unctuous), Madhura (sweet), Sheeta (cool) and Dra$v a$ (liquid) and lot of water is advised. Buffalo milk with little sugar is the drink of choice in summer. ${ }^{[14]}$ Buffalo milk is Madhura (sweet), Sheeta (cool), Snigdha (unctuous), that is why should be taken in Summer Season. In summer season temperature increases \& sweating occurs. During sweating loss of sodium and water occurs \& dehydration occurs. As the buffalo milk constitutes high sodium and water content, can be helpful in compensating the loss and maintain hydration.

As the body temperature rises, Proteins begin to deteriorate. Buffalo milk is excellent source of Proteins as it contains $4.3 \mathrm{~g}$ protein per $100 \mathrm{~g}$. During summer, daytime lasts longer than 12 hours. Buffalo milk is heavy, takes time to digest and keeps us fuller for longer period of time.

Winter Season: Sheep milk should be used in winter season i.e. in Hemanta Ritu. In Hemanta Ritu, pacification (Prashamana) of Pitta Dosha occurs. An individual's strength (Bala) \& digestive fire (Agni) stays at the highest level in this Ritu. So, the heavy food items can be easily digested. Madhura (sweet), Salty (Lavana), Sheeta (cool), Snigdha (unctuous) foods should be included in diet. ${ }^{[15]}$ As the sheep milk is Madhura (sweet), Lavana (salty), Guru (heavy to digest), Snigdha (unctuous) and Ushana (hot) in potency that is why should be taken in winter season. When digestive fire does not get the proper fuel, it affects the nutritive fluids, resulting in vitiation of Vata dosha. Because of Vatashamaka nature sheep milk is beneficial.

Sheep milk takes longer time to digest, can help to raise the body temperature $\&$ keeps the body warmer. Sheep milk contains fat in good amount. In winter season, our body uses fats to facilitate the absorption of vitamins A, E, K \& D. Sunlight aids in vitamin D absorption, \& most individuals get less sun when temperature drop.

Rainy Season: Cow milk should be used in rainy season i.e. in Varsha Ritu. In Varsha Ritu, accumulation (Sanchaya) of Pitta dosha and aggravation (Prakopa) of Vata dosha occurs. An individual's strength becomes weak during this season. Snigdha (unctuous) and Tridosh shamaka foods are indicated in this season. ${ }^{[16]}$ Cow milk provides strength i.e. Balya in nature. Cow milk is Snigdha (unctuous) and Tridosh shamaka i.e. why can be used in rainy season. Rainy season trigger our immune system, leading to infections. Cow milk contains about $88 \%$ of water. Water aids in boosting our immunity as they negate the building of toxins in our body. Cow's milk increases the Oja in our body. Oja is natural immunity of the body. Hence milk increases the immunity.

Cow Milk can be used in any season and every day. Ten properties of cow milk have been described in our texts. That are Swadu (Sweet), Sheeta (Cold), Mridu (Soft), Snigdha (Oily), Bahala (Thick), Shlakshna (Smoothness), Pichila(Sticky), Guru (Heavy), Manda (Slow), Prasanna (Clarity). These are also the properties of Ojas. Cow's milk increases the Oja in our body. It is better Jeevaniya Dravya \& Rasayana. ${ }^{[17]}$ According to the concept of Samanya \& Vishesha - 
Substances or Dravya are always enhanced by consuming same things. So intaking of Cow's milk increases the Oja in our body. According to Ayurveda, Oja is regarded to be the purest part of the seven dhatus \& is referred as Bala by Acharya Sushruta, the body's natural immunity. It is also known as Vyadhikshamatava. Our physical, mental \& spiritual strength is totally dependent on Oja. Achara Rasayana has been described in our texts in which milk is prescribed. As the milk is considered as a Rasayana.

Table 4: Comparison of utility of different milk in different season as per Ayurveda \& modern science

\begin{tabular}{|c|c|c|c|}
\hline Season & Rainy & Summer & Winter \\
\hline Milk & Cow & Buffalo & Sheep milk \\
\hline $\begin{array}{l}\text { As per } \\
\text { Ayurveda }\end{array}$ & $\begin{array}{l}\text { An individual's strength be- } \\
\text { comes weak during this season. } \\
\text { Cow milk provides strength i.e. } \\
\text { Balya in nature. }\end{array}$ & $\begin{array}{l}\text { Snigdha (unctuous), Madhura (sweet), } \\
\text { Sheeta (cool) and Drava (liquid) and lot } \\
\text { of water is advised. } \\
\text { Buffalo milk constitutes these properties. }\end{array}$ & $\begin{array}{l}\text { Guru (heavy to digest), Snigdha } \\
\text { (unctuous) and Ushana (hot) } \\
\text { Dravya are advised. } \\
\text { Sheep milk constitutes these } \\
\text { properties. }\end{array}$ \\
\hline $\begin{array}{l}\text { As per } \\
\text { modern } \\
\text { science }\end{array}$ & $\begin{array}{l}\text { Rainy season trigger our im- } \\
\text { mune system. } \\
\text { Cow milk contains about } 88 \% \\
\text { of water. } \\
\text { Water aids in boosting our im- } \\
\text { munity. }\end{array}$ & $\begin{array}{l}\text { Temperature increases \& sweating oc- } \\
\text { curs. } \\
\text { Loss of sodium and water occurs\& de- } \\
\text { hydration occurs. } \\
\text { Helpful in compensating the loss and } \\
\text { maintain hydration. }\end{array}$ & $\begin{array}{l}\text { In winter season, temperature } \\
\text { falls, and we feel colder. } \\
\text { It raises the body temperature \& } \\
\text { keeps the body warmer. }\end{array}$ \\
\hline
\end{tabular}

\section{CONCLUSION}

Milk provides special \& unique nutrition that cannot be derived from any type of food. Milk nourishes all the tissues, promotes balanced emotions and help to balance all the doshas. It is one of the most important foods to promote the Ojas. Ojas brings strength, strong immunity and happiness. It is beneficial for people of all age groups as a dietary supplement \& can be taken every day. It is also called Jeevaniya dravya. Hence there is no better life prolonger substance than milk.

\section{REFERENCES}

1. Kashyapa Samhita Or Vrddhajivakiya Tantra By Vriddha Jivaka Revised By Vatsya With Sanskrit Introduction By Nepal Rajaguru Pandit Hemraja Sharma With The Vidyotini Hindi Commentary \& Hindi Translation Of Sanskrit Introduction By Ayurvedalankar Sh. Satyapala Bhisagacharya, Chaukhambha Sanskrit Sansthan Varanasi, Reprint -2015, Kalpa Sthana Bhojankalpa Shloka 86- 87, Page No.-315.

2. Charak Samhita Of Agnivesha Revised by Charaka And Drdhabala, With Introduction By Vaidya-Samrata Shri Satya Narayana Shastri With Elaborated Vidyotini Hindi Commentary By Pt. Kasinatha Pandeya \& Dr.
Gorakhanath Chaturvedi, Editorial Board Pt. Rajeswaradatta Shastri, Part-1, Chaukhambha Bharti Academy Varanasi, Reprint -2013, Sutra Sthana 5/12, Page No.106.

3. Kashyapa Samhita Or Vrddhajivakiya Tantra By Vriddha Jivaka Revised by Vatsya With Sanskrit Introduction By Nepal Rajaguru Pandit Hemraja Sharma With The Vidyotini Hindi Commentary \& Hindi Translation Of Sanskrit Introduction By Ayurvedalankar Sh. Satyapala Bhisagacharya, Chaukhambha Sanskrit Sansthan Varanasi, Reprint -2015, Kalpa Sthana Bhojankalpa Shloka 90, Page No.-315.

4. Bhavprakasha Of Shribhava Misra (Including Bhavprakasha Nighantu Portion) Edited with the 'Vidyotini' Hindi Commentary Notes \& Appendix By Sri Brahmasankara Misra And Sri Rupalalaji Vaisya First Part, Chaukhambha Sanskrit Bhawan Varanasi, Edition Twelfth, 2018, Dugdh Varga- Shloka- 02, Page No.906.

5. Sushruta Samhita Of Maharsi- Susruta By Kaviraja Ambikadutta Shastri, Part-1, Chaukhambha Sanskrit Sansthan Varanasi, Reprint -2015, Sutra Sthan 45/6162, Page No.-224.

6. Community Medicine with Recent Advances By AH Suryakantha, Fourth Edition :2017, Chapter-16, Page 
No.-175, Publisher - JAYPEE The Health Sciences Publisher.

7. Sushruta Samhita Of Maharsi- Susruta By Kaviraja Ambikadutta Shastri, Part-1, Chaukhambha Sanskrit Sansthan Varanasi, Reprint -2015, Sutra Sthan 45/5052,54-55, Page No.-223.

8. Charak Samhita Of Agnivesha Revised By Charaka And Drdhabala, With Introduction By Vaidya-Samrata Shri Satya Narayana Shastri With Elaborated Vidyotini Hindi Commentary By Pt. Kasinatha Pandeya \& Dr. Gorakhanath Chaturvedi, Editorial Board Pt. Rajeswaradatta Shastri, Part-1, Chaukhambha Bharti Academy Varanasi, Reprint -2013, Sutra Sthana 27/217-219,222-223,Page No.-550 \& 551.

9. Bhavprakasha of Shribhava Misra (Including Bhavprakasha Nighantu Portion) Edited With The 'Vidyotini' Hindi Commentary Notes \& Appendix By Sri Brahmasankara Misra And Sri Rupalalaji Vaisya First Part, Chaukhambha Sanskrit Bhawan Varanasi, Edition Twelfth, 2018, Dugdh Varga- Shloka- 7-8,15-19, Page No.-906, 907\& 909.

10. Harita Samhita Text Sanskrit Moola \& 'Nirmala' Hindi Commentary By Vaidya Jaymini Pandey, Chaukhambha Visvabharati Varanasi, Prathama Sthana 8/20 Page No.-63

11. Community Medicine with Recent Advances By AH Suryakantha, Fourth Edition :2017, Chapter-16, Page No.-175, Publisher - JAYPEE The Health Sciences Publisher.

12. Materia Medica Of Ayurveda, Bhagwan Dash \& Lalitesh Kashyap, Todarananda Ayurveda Sankhyam Series 1 Chapter 6/41, Page No.-152.

13. Astang Hridyam Sutra Sthana By Prof. Ravidutt Tripathi, Chaukhambha Sanskrit Pratishthan, Delhi, Reprint -2012, Sutra Sthana 12/24-27, Page No.-195 \&196.

14. Astang Hridyam Sutra Sthana By Prof. Ravidutt Tripathi, Chaukhambha Sanskrit Pratishthan, Delhi, Reprint -2012, Sutra Sthana 3/28\&32, Page No. - 49\&50.

15. Charak Samhita Of Agnivesha Revised By Charaka And Drdhabala, With Introduction By Vaidya-Samrata Shri Satya Narayana Shastri With Elaborated Vidyotini Hindi Commentary By Pt. Kasinatha Pandeya \& Dr. Gorakhanath Chaturvedi, Editorial Board Pt. Rajeswaradatta Shastri, Part-1, Chaukhambha Bharti Academy Varanasi, Reprint -2013, Sutra Sthana 6/9, Page No.-139.

16. Charak Samhita Of Agnivesha Revised By Charaka And Dr Dhabala, With Introduction By VaidyaSamrata Shri Satya Narayana Shastri With Elaborated
Vidyotini Hindi Commentary By Pt. Kasinatha Pandeya \& Dr. Gorakhanath Chaturvedi, Editorial Board Pt. Rajeswaradatta Shastri, Part-1, Chaukhambha Bharti Academy Varanasi, Reprint -2013 , Sutra Sthana 6/33-34, Page No.-143.

17. Charak Samhita Of Agnivesha Revised By Charaka And Drdhabala, With Introduction By Vaidya-Samrata Shri Satya Narayana Shastri With Elaborated Vidyotini Hindi Commentary By Pt. Kasinatha Pandeya \& Dr. Gorakhanath Chaturvedi, Editorial Board Pt. Rajeswaradatta Shastri, Part-1, Chaukhambha Bharti Academy Varanasi, Reprint - 2013, Sutra Sthana 27/217 \& 218, Page No.-550 \& 551.

\section{Source of Support: Nil \\ Conflict of Interest: None Declared}

How to cite this URL: Rana Shivani et al: Comparative Analysis And Seasonal Uses Of Different Animal Sources Of Milk Given In Various Ayurveda Texts. International Ayurvedic Medical Journal \{online\} 2020 \{cited October, 2020\} Available from: http://www.iamj.in/posts/images/upload/4766 4771.pdf 